\title{
QUARRELING SIBLINGS OR FRIENDLY NEIGHBOURS? TURBULENT NATURE OF INDO-PAKISTAN RELATIONSHIP SINCE 1947
}

\author{
Shantanu Chakrabarti ${ }^{1}$ \\ Institute of Foreign Policy Studies (IFPS), University of Calcutta
}

\begin{abstract}
:
The process of decolonization and partition in South Asia led to internal discrepancies and evolution of regional dynamics often competitive and conflict-prone in nature. This has been particularly true in case of evolving bilateralism between India and Pakistan since 1947. While intermittent conflicts along with continuous tension and rivalry have been main features of the bilateral relationship, it has not been a case of unrelenting hostility on both sides. There have been 'bright spots' of engagement connecting the two countries at various official and non-official levels of engagement. Betterment of ties has become particularly essential as regional dynamics has eased to be a 'zero-sum' game for either country in the post Cold period as a 'failed' or 'radicalized and 'balkanized' Pakistan would not only jeopardize any prospects of peace and stability in South Asia but would also become a terrible global problem.
\end{abstract}

Keywords: South Asia, India, Pakistan, Ethnicity, Nationalism, Partition, Rivalry, Cooperation, Conflict.

\section{Resumen:}

El proceso de descolonización y la partición en el sur de Asia, dio lugar a discrepancias internas y la evolución de las dinámicas regionales a menudo competitivas y con propensión al conflicto. Esto ha sido particularmente cierto en el caso de la evolución de las relaciones bilaterales entre India y Pakistán desde 1947. Aunque los conflictos intermitentes, la tensión continua y la rivalidad han sido características principales de la relación bilateral, no ha existido una implacable hostilidad en ambos Estados. Han existido puntos brillantes de acercamiento, conectando a los dos países en distintos niveles de compromiso oficiales y no oficiales. La mejora de las relaciones ha llegado a ser esencial, ya que la dinámica regional ha llegado a convertirse en un juego de "suma cero" para uno u otro país en el período posterior de la Guerra Fría, dado que el "fracasado" o "radicalizado y" balcanizado" Pakistán no sólo pondría en peligro las perspectivas de paz y estabilidad en el sur de Asia, sino también se convertiría en un terrible problema global.

Palabras clave: Sur de Asia, India, Pakistán, etnia, nacionalismo, partición, rivalidad, cooperación, conflicto.

Copyright (C) UNISCI, 2012.

Las opiniones expresadas en estos artículos son propias de sus autores, y no reflejan necesariamente la opinión de UNISCI. The views expressed in these articles are those of the authors, and do not necessarily reflect the views of UNISCI.

\footnotetext{
${ }^{1}$ Associate Professor, Dept. of History \& Convenor, Academic Committee, Institute of Foreign Policy Studies, University of Calcutta, Kolkata, India. Research areas: South Asian regional dynamics; Indian foreign policy; Peace and Conflict studies; security privatization.

Address: Institute of Foreign Policy Studies (IFPS), University of Calcutta (Alipore campus) (4th Floor), 1 Reformatory Street, Kolkata, 700027, India.

E-mail: chakrabartishantanu@hotmail.com.
} 


\section{Introduction}

Nothing perhaps influences the skeptical global opinion on South Asia more than the continuous impasse in Indo-Pakistan relations. India-Pakistan are asymmetrical dyads representing different levels of democratization, with Pakistan, 'on its way to democratization,' while India has democratized to a much larger extent. ${ }^{2}$ Between 1947 and 2012 , both countries have fought three full scale wars $(1947-48 ; 1965 ; 1971)$ and a severe localized conflict at Kargil in the Jammu Kashmir region in 1999. Such conflicts generate global concern for the region particularly as the stakes have become higher with the overt nuclearization of the two countries in 1998 and the unleashing of the global war on terrorism since the 9/11 incident and its deleterious impact in the 'Af-Pak' region.

Yet, it has not always been a case of unrelenting hostility on both sides determined to finish each other off. Both countries have been founding members of the only regional organization, the South Asian Association for Regional Cooperation (SAARC), set up in 1985. Non-state groups and civil society communication channels between the two countries have proliferated over time and such connectivity has endured period of severe tension when official communications were almost nil. Some of these groups have been working for long in ensuring people to people contact process at multiple levels. Bilateral trade and economic interactions have continued during periods of stand offs and the recent announcement of the Pakistani government of plans to grant Most Favoured Nation(MFN) status to India by the end of 2012, thereby fulfilling a basic requirement of the South Asian Free Trade Agreement(SAFTA), has brightened the prospect of improving bilateral trade potential. Even during periods of war and hostility both Indian and Pakistani armies have showed considerable restraint sparing civilian targets, limiting casualty rates and treating the prisoners of war (POWs) in a humane manner. ${ }^{3}$

For a better understanding, the evolving Indo-Pakistan bilateralism needs to be contextualized within the South Asian regional setting. The South Asian region is an 'Indocentric' region because of the strategic location of India straddling the region, her geographical size and extent, her vast population and her superiority in terms of military, economic and soft power. But this has not resulted in unambiguous acceptance of her 'hegemony' on the part of the South Asian countries. In fact, projection and exercising of Indian hegemony in the region has been a complex and evolving affair, not uniform in character and often contested. India's South Asian neighbors have continuously sought to deny or negate this preeminence by seeking to limit India's regional hegemony. This has resulted in regional rivalry and tension expressed through steady rise in military expenditure and defense spending, including the overt nuclearization of the regional rivals, India and Pakistan in 1998. The region in this sense could be also characterized as a 'security complex' constituting a subsystem of the global community of states that for reasons related to historical, geo-strategic and socio-cultural linkages have an interlinked security architecture. This particularly gets reflected in India's relationship with Pakistan, the second largest state in South Asia, which also has been more successful in challenging India's regional hegemony than other countries.

\footnotetext{
${ }^{2}$ Suzuki, Akisato and Loizidez, Neophytos: "Turkey and India -Escalation of interstate crises of conflictual dyads: Greece-Turkey and India-Pakistan”, Cooperation and Conflict, vol. 46, no. 1 (March 2011), p.22.

${ }_{3}^{3}$ Mazari, Shirin M. (2002): "Developing and Enhancing CSBMs in South Asia", in Banerjee, Dipanka (ed.): South Asian Security: Futures: A Dialogue of Directors Regional Strategic Studies Institutes, Colombo, Regional Centre for Strategic Studies (RCSS), p. 89.
} 


\section{The Background}

\subsection{Roots of Indian Policymaking}

Some analysts have argued that acting under cross-pressure, India's foreign policy appears to vacillate between appeasement and aggression, rather than converging onto the assertion of national self-interest. ${ }^{4}$ Understanding the complexities involved in Indian policy making requires one to remember the colonial legacy inherited by the new nation state which could not initiate foreign policy making on a clean slate since 1947. Under British colonialism, there were certain attempts to project India as a major strategic centre of Britain's Afro-Asian empire. The Indian policymakers developed a deeply ambivalent relationship with this sort of policy projection after independence. On the one hand there was rejection at one level of the colonial state's power projection as an 'imperialist scheme' which must be rejected after independence. On the other hand, assertions that India would continue to play a leading role in Asian affairs if not in the world, not as a military power, but as a benevolent leader, continued to be expressed in nationalist thinking on foreign affairs. In connection with policy making in South Asia it has to be admitted that while India has been a mildly revisionist state at the level of the international system, its regional agenda for the past several decades has been to buttress the regional status quo for the simple reason that the current configuration of regional capabilities suits it. ${ }^{5}$ Indian neighbors, particularly Pakistan, on the other hand, as irredentist powers have sought to resist this policy making to the best of their capabilities.

Nehru's 'Asianism,' however, did not really have its focus upon South Asia. India, in fact, India under Nehru (1947-1964) consciously avoided growth of multilateralism in South Asia and put more emphasis on bilateralism with other countries. Regional relations, particularly with Pakistan and Sri Lanka, continued to suffer over disputes over contested territories (the status of Jammu and Kashmir); treatment of minorities (Hindu Bengalis in East Pakistan and Tamils in Sri Lanka); and water sharing, in spite of various agreements being signed from time to time. Indian foreign policy was to develop a greater regional focus only under Lal Bahadur Shastri (1964-1966) who increased Indian engagement in South Asia. Regional policy pursued during the 1970s and 1980s (with a brief period of Janata Party government at the Centre from 1977 to 1980) under the premiership of Indira Gandhi and Rajiv Gandhi became more activist and often interventionist in nature as proven by the IndoPakistan war of 1971 leading to the secession of East Pakistan and its emergence as Bangladesh. India would also increase her engagement in South Asia during the post Cold war period particularly as she faced greater strategic threats in the region.

\subsection{Roots of Pakistani Policymaking}

When Pakistan emerged as an independent country following the partition of the Indian subcontinent in 1947 along with India, it was the world's fifth most populous nation, but three of the four above it-China, India, and the Soviet Union-were its nearby neighbours leading to the perpetuation of a 'minority syndrome.' Pakistanis came to think of themselves as a small country that had to shape its foreign and security policies accordingly. To make matters still

\footnotetext{
${ }^{4}$ Mitra, Subrata K. and Schöttli, Jivanta: “The New Dynamics of Indian Foreign Policy and Its Ambiguities', Irish Studies in International Affairs, vol. 18 (2007), p. 21.

5 Sahni, Varun: "The Protean Polis and Strategic Surprises: Do Changes within India affect South Asian Strategic Stability?", Contemporary South Asia, vol.14, no.2 ( 2005), p. 219.
} 
worse, Pakistan came into existence split in two and lacking strategic depth; its borders were ill defined and indefensible, dividing ethnic groups. ${ }^{6}$ According to one author, for instance:

Pakistan is placed in a unique historical and geostrategic situation. On the East, we are bordered by India, with a population of 650 million; on the North we share borders with the world's most populous nation, China. The Soviet superpower has its borders only 25 miles from Pakistan's northern frontiers. On the West, Pakistan not only shares borders with Iran but is situated at the mouth of the Persian Gulf, the region where two-thirds of the world's exportable oil is produced. Pakistan is placed in an especially vulnerable position. It cannot help but be affected by its sensitive strategic location, the regional history of great power rivalry, and finally, the unique situation of Pakistan's creation and the historical strife with India. ${ }^{7}$

Many scholars have traced the origin of Indo-Pakistan conflict to ethno-national rivalry between Hindus and Muslims who became increasingly politicised communities during the colonial period, and to the emergence of the 'Two Nation' theory and the concept of a separate 'Muslim homeland' and its realization in 1947. One scholar has even traced back the ideological and cultural roots of today's Pakistan in the proto-historic Indus Valley/Harappan Civilization different from an essentially Indic or Ganjetic based Indian civilization. ${ }^{8}$ The bitter legacy of partition along with large scale human displacement and unspeakable misery affected bilateral relations in the immediate years after partition and independence. When the pre-1947 two nations theory was married to the post-1947 theory of India's hegemonic threat to Pakistan, the state ideology and policy required the exacerbation of differences with India. ${ }^{9}$ As one analyst argues:

(T)he short-term, day-to-day policies of India and Pakistan are made within the context of the long-term norm of behavior that exists between the two rivals...this norm, or equilibrium level of behavior, has been characterized by high levels of sustained hostility punctuated by an intense ideological, religious, and political rivalry. This underly-ing norm provides the context for day-to-day foreign policy behavior; the short-run adjustments of foreign policy behavior occur within this context. ${ }^{10}$

Pakistanis excluded the possibility of accommodation and acceptance of Indian regional leadership as a means of ensuring their own national well being. After all, they defined their very rationale for existence as being 'not India' and the heritage of conflict had been

\footnotetext{
${ }^{6}$ Thornton, Thomas Perry (1999): "Pakistan: Fifty years of Insecurity", in Harrison, Selig S.; Kreisberg, Paul H.; Kux, Denis (eds.): India and Pakistan:The First Fifty Years, Washington DC, Woodrow Wilson Center, Cambridge University Press, p.171.

7 Khan, Sultan Muhammed: "Pakistani Geopolitics: The Diplomatic Perspective", International Security, vol. 5, no. 1 (Summer, 1980), pp.26-27.

${ }^{8}$ For details see, Ahsan, Aitzaz (1996): The Indus Saga and the Making of Pakistan, Karachi, Oxford University Press.

9 Kapur, Ashok (2005): "Major powers and the persistence of the India-Pakistan conflict", in Paul, T.V. (ed.): The India-Pakistan Conflict: An Enduring Rivalry, Cambridge, Cambridge University Press, p.142.

${ }^{10}$ Rajmaira, Sheen: "Indo-Pakistani Relations: Reciprocity in Long-Term Perspective",

International Studies Quarterly, vol. 41, no. 3 (September 1997), p. 549.
} 
intensified by orders of magnitude through the horrors of partition. ${ }^{11}$ As Yasmeen and Dixit(1995) comment in their study:

\begin{abstract}
The dominant view of India among the Pakistani elite is one of an expansionist, arrogant and bullying state that did not accept the idea of partition and/or the basis on which the partition took place... India is credited with an uncontrollable urge to destroy Pakistan and reintegrate it with the larger India or at least to subjugate Pakistan and relegate it to subordinate status...The dominant view of Pakistan within the Indian elite is one of a theocratic, religiously fanatic and militaristic state...seen as denying its cultural links with the Indian civilization...At the same time, it is accorded a sense of vengeance which motivates Pakistan to undermine the secular basis of Indian polity by meddling in Kashmir, Punjab, and India's financial nerve center, Bombay. ${ }^{12}$
\end{abstract}

The Islamic heritage was sought to be highlighted often as a state project in order to create a distinct identity for Pakistan as a state. The state was declared to be an Islamic Republic in 1947 and the Objective Resolutions were adopted in 1949. Subsequently, the concept of the Islamic state was included in the preamble of the Constitution in 1956 and in the 1962 and 1973 versions of the Constitution also. Islamization process received a further boost under Bhutto during 1976-1977, particularly after the secession of East Pakistan following the IndoPakistan war of 1971. The appeal of Islam, according to one author, apparently has been abused to retain the feudal-capitalist stranglehold over Pakistani socio-economic and political structure. As he notes:

As Pakistan became a model of neo-colonial and imperialist serfdom, a superficially Islamic gloss was gradually applied to the capitalist/feudalist system and became an ideology of the upper classes. This fact is also reflected in Pakistan's three constitutions which were framed in 1956, 1962 and 1973. The provisions of these constitutions left all means of production in the hands of the bourgeois/feudal class. The structure of feudalism remained intact and industry and finance came to be concentrated within a few powerful groups. ${ }^{13}$

Bhutto's tentative steps towards creation of 'Islamic Socialism' involved labor friendly legislation and nationalization of key industries, banks and insurance companies, but without any clear policy on how these sectors were to contribute towards economic growth after nationalization. Not surprisingly, the post-nationalization era recorded a sharp decline in industrial growth rates. ${ }^{14}$ The process, anyway, would be abandoned after the fall of Bhutto in 1977.

\footnotetext{
${ }^{11}$ Thornton, op. cit., p.171.

12 Yasmeen, Samina and Dixit, Aabha: "Confidence- Building Measures in South Asia”, Occasional Paper, no.24 (September 1995), pp.10-11.

${ }^{13}$ Haque, Ziaul: "Pakistan and Islamic Ideology" in Gardezi, Hassan; Rashid, Jamil (eds.) (1983): Pakistan: The Roots of Dictatorship, the Political Economy of a Praetorian State, New Delhi, Oxford University Press, p.378.

14 Khan, Tariq Amin: "Economy, society and the state in Pakistan", Contemporary South Asia, vol. 9 , no.2 (2000), p.184.
} 
In terms of foreign policy making, Bhutto also emphasized Pakistan's west Asian and Arab linkages which included sending of Pakistani military contingents in various west Asian countries. Pakistan, however, never received overwhelming support from the west Asian countries. During the Indo-Pakistan war of 1971, for instance, long-standing friendship, political interests, nonalignment, and membership in the Third World led to the countries like Syria, Algeria and Egypt taking a neutral stand while countries like Libya, Jordan and Saudi Arabia supported Pakistan. ${ }^{15}$ Following India's nuclear test at Pokhran conducted in 1974, Bhutto announced Pakistan's determination to produce an 'Islamic bomb' as a countermeasure against the 'Hindu' bomb or the 'Jewish' bomb, managing to get favorable response from the Arab states, still smarting under the defeat at the hand of Israel in 1973, resulting in flow of funds and economic aid from the Arab states to Pakistan. ${ }^{16}$ General Zia ul Haq (1977-1988) further Islamized the polity by introducing the Hudud (Islamic Criminal law) as part of the Pakistan's penal code during his rule. The process of Islamization has been attributed to the politicization of Islam by the short-sighted political leaders, who made compromises with extremist elements in society, in order to stay in power. ${ }^{17}$ General Zia, it has been argued, was also primarily responsible in grafting military officials into key positions within the civilian administration as well as in semi-government and autonomous organizations. ${ }^{18}$ The Eight Amendment of 1985 also helped Zia to retain his authoritarian form of government even after martial rule was lifted.

No Pakistani government undertook efforts to reverse the Islamization of the constitution and the legal system. The vagueness of the battle cry 'shariah' makes this term useful for particularly propaganda purposes, but contributes to the state of uncertainty of public opinion. ${ }^{19}$ The Islamic card is also regularly invoked in projection of Pakistan's foreign and strategic policy making. In case of India, for instance, it has been argued that, the loss of East Pakistan forced Pakistan to re-imagine itself in terms that enhanced its Islamic identity and brought it more self-consciously in line with radical interpretations of a state based on Islam. With it came a shift in how Kashmir's relation to Pakistan's identity came to be represented. The focus no longer lay in projecting Pakistan as a Muslim homeland to which Kashmir as a Muslim majority province. Instead, Kashmir was recast as sacred territory awaiting liberation through jihad - thus authenticating Pakistan's identity as the protector of Islam. ${ }^{20}$ Sind and in Balochistan, where substantial sections of the population question the legitimacy of Punjabi hegemony, on the whole, have displayed less devotion to the Kashmiri cause which has been more pronounced in the Punjab. ${ }^{21}$

Madrassahs also play a crucial role in spreading and popularizing the concept of jihad. As one analyst notes, "examination of the syllabi and curriculum of the Pakistani madrassahs show that in the name of refutation,... pungent criticism of the other sects, hatred towards

\footnotetext{
${ }^{15}$ Saliba, Najib E.: "Impact of the Indo-Pakistani War on the Middle East",

World Affairs, vol. 135, no. 2 (Fall 1972), pp. 129-137.

${ }^{16}$ Shah, Mehtab Ali (1997): The Foreign Policy of Pakistan: Ethnic Impacts on Diplomacy, London, IB Taurus, p.27.

${ }^{17}$ Iqbal, Javid (2003): Islam and Pakistan's identity, Lahore, Iqbal Ascendancy, p.361.

18 Bose, Sugata and Jalal, Ayesha (1999): Modern South Asia: History, Culture, Political Economy, New Delhi, Oxford University Press, p.233.

${ }^{19}$ Kleiner, Juergen: "Pakistan: An Unsettled Nation”, Diplomacy \& Statecraft, vol.18, no. 1 (2007) p.3.

${ }^{20}$ Shaikh, Farzana (2009): Making Sense of Pakistan, New York, Columbia University Press, p.187.

${ }^{21}$ Ibid., p. 188.
} 
other sect members, and a siege mentality are imparted from the very beginning of the schooling." 22

\section{Kashmir: The Eye of the Storm}

While Indo-Pakistan bilateral differences continue over issues like the Siachen Glacier, the Sir Creek maritime boundary, or the Baglihar navigation project, the territorial dispute between India and Pakistan over Jammu and Kashmir continues to be one of the most enduring and intractable problem for over sixty five years now. The emergence of the problem as a result of the disputed accession of the kingdom ruled by a Hindu ruler but having a Muslim majority to the Indian Union in 1947 under difficult circumstances and the consequent territorial dispute over it is too well known to be elaborated here. Following the 1947-48 war, a cease fire line (CFL) was created to divide the Indian Jammu and Kashmir from the Pakistani occupied Kashmir (POK) (known in Pakistan as the Azad Kashmir). The CFL was converted into a Line of Control following the 1971 war and the Simla agreement of 1972. Both countries accepted the legality of the CFL, although by not demarcating the line beyond map coordinates NJ 9842, room for dispute over the Siachen Glacier was left open, making it the highest battlefield on the earth. ${ }^{23}$ Both India and Pakistan, however, officially do not accept the LOC as final. The Indian parliament passed an official resolution in 1994 which commits the Indian state to work for the recovery of the territory under POK. It would also be suicidal for any Pakistani government to publicly abandon the issue of Kashmir. The provision for a plebiscite in accordance with the 13 August 1948 United Nations Commission for India and Pakistan(UNCIP) resolution was rendered obsolete on account of Pakistan's refusal to comply with Parts I and II of the same resolution, "which among other things, dictated the evacuation of J\& K territory under Pakistani occupation."24

One lamentable factor in this whole complex affair has been the relative negligence of aspirations of the indigenous population in the region. This has included the Hindu Pandits forced to abandon their homes in the valley living as refugees in Delhi or the Shiites and the tribal Muslim communities along with the Buddhists in Leh who generally disagree with the majority Sunni population in valley on questions of autonomy, independence or even merger with Pakistan. Nor can it be denied that the Indian state's essentially coercive approach has led to further alienation of the local population. In Amnesty International's view there has been a pattern of gross human rights violation in the region. This perhaps explains the scale of local upsurge during the 1980s and the 1990s buoyed by large scale support from Pakistan.

The fate of the indigenous population in the POK has perhaps been worse. Pakistan occupied Kashmir (PoK) consists of the so called 'Azad Jammu and Kashmir (AJK)' and 'Gilgit-Baltistan' (referred to as the 'Northern Areas' till August 2009). Continuous neglect of their legitimate demands for development and proper representation has generated resentment against the authorities in Islamabad. According to one recent study:

The popular resentment against Pakistan is increasing day by day. The growing footprint of China in the region adds yet another strategic

\footnotetext{
${ }^{22}$ Riaz, Ali: "Global Jihad, Sectarianism and the Madrassahs in Pakistan”, Working Paper, no. 85 (August 2005), The Institute of Defence and Strategic Studies (IDSS), pp.19-20.

${ }^{23}$ Ramachandran, Sudha: "Kashmir in Focus, Part 3: Drawing the Lines", Asia times Online (26 January 2002), at http://www.atimes.com/ind-pak/DA26Df02.html.

${ }^{24}$ Ray, Jayanta Kumar (2011): India’s Foreign relations, 1947-2007, New Delhi, Routledge, p.177.
} 
dimension to the discourse on PoK. These realities are certain to impinge on India's long-term security interests and therefore it is incumbent upon Indian policy makers to adopt a proactive approach towards PoK which is an integral part of India. India should not only rethink its approach but also try and mobilize international opinion against bad governance and unlawful occupation of PoK by Pakistan since $1947 .^{25}$

The Institute of Gilgit and Baltistan Studies, an organization set up by the indigenous people of the region mostly settled in the US, continues to highlight the deplorable conditions in the region through their website. The Institute, among other things, demands demilitarization of Gilgit-Baltistan, political and judicial autonomy, genuine democracy, and elimination of extremism and terrorism from the region. ${ }^{26}$ In an effort to meet long-simmering demands for greater autonomy, Pakistan's Pakistan People's Party-led government granted this region limited autonomy, including their own elected assembly in 2009 but this has failed to satisfy the local population. According to one local activist, Baba Jan, "We want our assembly to decide whether to join China, Pakistan, or India - but I'd prefer independence." 27 A political formation called the Balawaristan (occupied Gilgit Baltistan) National Front (BNF) was also formed on July 30, 1992 which has prepared the manifesto of a sovereign and independent Republic of Balawaristan in spite of facing coercive policy of the Pakistan government. ${ }^{28}$

\section{Evolving Relationship, Local Dynamics and Extra-Regional Factors (1947-2000)}

Essential differences and contesting sub-nationalisms within Pakistan could not be properly covered by the drape of statist Islamist project. The force of centripetal Islamic appeal is offset by the centrifugal pulls of regional, ethnic and linguistic identities. The myopic management of politics of the state by the ruling elite complicates the process of nationbuilding and contributes to the fragility of the 'Pakistani' nationhood. ${ }^{29}$

Initially, the main elite group was the Muhajirs, émigrés from India. Following Liaqat Ali Khan's assassination in 1951, the Muhajir power base, however, started to shrink. The military takeover in 1958, under army chief General Ayub Khan, a Pashtun, established the dominant role of Punjab in the Pakistani power structure with an alliance with the Pashtuns. In 1960, Ayub Khan shifted the capital from Karachi to Rawalpindi, a garrison city of Punjab, further undermining the Muhajir influence (Islamabad officially made the capital in 1967). ${ }^{30}$ It has been argued that because, "Pakistanis sensed the insecurity, they often clutched at

\footnotetext{
25 "Pakistan Occupied Kashmir: Changing the Discourse", IDSA POK Project Report (May 2011), New Delhi, Institute for Defence Studies and Analyses (IDSA), p.34.

${ }^{26}$ For details see, http://www.gilgitbaltistan.us/About-Us/about-us.html.

27 Ahmed, Issam: "In Pakistan-controlled Kashmir, residents see experiment with autonomy as 'illusion', The Christian Science Monitor (28 May 2011), at

http://www.csmonitor.com/World/Asia-South-Central/2011/1128/In-Pakistan-controlled-Kashmir-residents-seeexperiment-with-autonomy-as-illusion.

${ }^{28}$ For details see, Balwaristan National Front website at, http://www.balawaristan.net/.

${ }^{29}$ Behuria, Ashok K.: "Myth of the Monolith: The Challenge of Diversity in Pakistan", Strategic Analysis, vol. 29, no.1 (Jan-March 2005), p. 61.

30 Munir, Imran: "From Independence to Fundamentalism: Pakistan's Search for Identity", Critical Asian Studies, vol. 39, no. 4(2007), p. 626.
} 
strong leaders, looking for a Saladin." ${ }^{31}$ Given the weakness of political formations, there is, therefore, little wonder that the army has played a dominant role within the internal power structure of Pakistan along with the task of playing a crucial role in determining the country's foreign policy making particularly vis a vis India. The army has, so far, imposed military dictatorship in Pakistan four times in its political history (1958; 1969; 1978; and, in 1999). Even during intermittent periods of civilian rule, the army along with the ISI (Inter Services Intelligence) continues to dominate the decision making structure. The noted Pakistani scholar Ayesha Siddiqa has shown in detail how the military has gradually gained control of Pakistan's political, social, and economic resources transforming in the process the Pakistani society, where the armed forces have become an independent class. ${ }^{32}$

What helped them was the successful projection of Pakistan as strategically crucial partner straddling West Asia and Central Asia in stemming the tide of Soviet aggression. US support for the establishment, particularly the Pakistan army, proved to be a crucial factor in elevating the status and prestige of the army. Pakistan signed a military pact with the USA in 1954 and the partnership was sought to be further strengthened by Pakistan's participation in the SEATO (Southeast Asia Treaty Organization) and the Baghdad Pact, which later became the CENTO (Central Treaty Organization).United States-Pakistan relationship has, it has been argued "veered between alliance intimacy and cordiality and times of friction and tension, but has also seen periods of standoffishness and indifference." 33 Though Pakistan army made liberal use of the US supplied arms and ammunitions including Patton tanks, despite the US claim that these were meant for defense against Communist aggression, during the IndiaPakistan war of 1965, the US suspended arms shipments to both India and Pakistan. American military assistance to Pakistan and the use of Islamabad in the US-China rapprochement process also gave rise in India to fears of an emerging US-China-Pakistan axis which in turn brought India and the Soviet Union closer leading to the signing of the bilateral Treaty of Friendship and Cooperation in $1971 .{ }^{34}$ More US support, however, came during the IndiaPakistan war in 1971(leading to the creation of Bangladesh) when the United States dispatched to the Bay of Bengal a task force headed by the Enterprise, a nuclear powered aircraft carrier as a sign of symbolic intimidation. The deliberate neglect of the pogrom committed by the Pakistani army in East Pakistan and efforts to help the Pakistani government during the war of 1971 clearly indicated the Nixon-Kissinger administration's determined efforts to support the Pakistani military establishment at almost any cost.

Given the fact that Pakistan's relations with the USA has not been always smooth Pakistan has also been on a search for other allies who could help in enhancing her strategic power in relation to India. In this connection, China has proven to be crucial ally. China's basic aim, on the other hand, is to use Pakistan to arrest India's projected rise keeping her engaged with South Asian strategic threats. Sino-Pakistan strategic partnership presents India with a two-front threat: Pakistan in the west and China in the north and north-east making it difficult for India to concentrate its forces on either front and weakening her ability to seal with either potentially hostile party. ${ }^{35}$ In December 1961 Pakistan voted in favor of granting

\footnotetext{
31 Ahmed, Akbar S. (1997): Jinnah, Pakistan and Islamic Identity: the Search for Saladin, Oxford, Oxford University Press, p.205.

${ }^{32}$ For details see, Siddiqa, Ayesha (2007): Military Inc: Inside Pakistan's Military Economy, UK, Pluto Press.

${ }^{33}$ Kux, Dennis (2001): The United States and Pakistan, 1947-2000, Oxford, Oxford University Press, p. 359.

${ }^{34}$ Kumar, Sushil: "Power Cycle Analysis of India, China, and Pakistan in Regional and Global Politics", International Political Science Review / Revue internationale de science politique, vol.24, no.1 (January 2003), p.118.

${ }^{35}$ Atwal, Amardeep (2008): China-India Relations: Contemporary Dynamics, UK, Routledge, p.43.
} 
UN membership to the Peoples' Republic of China even at the risk of alienating the USA. ${ }^{36}$ Pakistan and China had also signed a treaty on border alignment in the POK region in spite of Indian protests. By 1971, two roads linking the Xinjiang province of China and Azad Kashmir had been constructed but more significant was the completion of the four lane Karakoram Highway which became operational in 1982 making it the world's highest international highway. ${ }^{37}$ Growing dependence on China as a strategic partner was proven by the declaration of the partnership as an "all weather friendship." Pakistanis may proudly hail A. Q. Khan as the father of the 'Islamic bomb,' and he may have been responsible for stealing blueprints for the manufacture of enriched uranium from a Dutch laboratory in 1972, but was initially little involved with the actual design, development and testing of Pakistan's nuclear weapons and was only put in charge of Pakistan's uranium enrichment program in 1976. The Pakistani nuclear programme was, in fact, primarily developed under Chinese help. ${ }^{38}$ Chinese deliberate proliferation of nuclear and ballistic missile technology to various non-western countries, in fact, pales into comparison to the help China gave to Pakistan during the 1980s in order to redress the perceived nuclear imbalance in South Asia. ${ }^{39}$ Chinese transfer of technology and nuclear weapon design and training of Pakistani scientists in China was followed by, what is generally accepted, the Chinese testing of Pakistan's first atomic weapon on their behalf at Lop Nur test site on 26 May 1990. ${ }^{40}$ In the 1990s Pakistan also received Na Dong ballistic missile technology from North Korea perhaps in return of A.Q. Khan's uranium enrichment technology. ${ }^{41}$

India, on the other hand, has continued to perceive herself as the true inheritor of the legacy of the colonial state and has been anxious to maintain and project her importance in decolonized Asia, particularly in her immediate neighborhood of South Asia. This was true even during Nehru's period (1947-1954) when South Asia was not regarded as a priority area for Indian policy makers and certainly more vigorously followed by successor leaders. One essential element of this policy involved attempts to keep at bay, foreign powers as far as possible, from this region and preferring the bilateral resolution of existing differences without external mediation or intervention. In this sense, India could be characterized as a 'status quo' power, trying to maintain the established patterns of regional relations. This policy did not always succeed as India could neither prevent growing ties between the USA and Pakistan or Sino-Pakistan collaboration. Nor did it have much say in the Soviet invasion in Afghanistan in 1979, in spite of being one of its close allies.

Certain changes were evident in the Indian regional policymaking since the 1990s. Such changes were a part of the shifting outlook of India's external relations. The 'crossing of the Rubicon' decision was largely an attempt to adjust to the shifting paradigm of the global order in the post Cold War period, the collapse of the Soviet Union, and also to the onset of the globalization process. In terms of greater engagement with the South Asian neighborhood, the clear articulation came from I.K.Gujaral, in his capacity as the foreign minister and later on the prime minister in the United Front government (1996-1998). Eponymously known as the

\footnotetext{
${ }^{36}$ Ray, op. cit., p. 135.

${ }^{37}$ Vertzberger, Yaacov: "The Political Economy of Sino-Pakistani Relations: Trade and Aid 1963-82", Asian Survey, vol. 23, no. 5 (May, 1983), p. 643.

38 Norbu, Jamyang: "Who Created Pakistan's Nuclear Arsenal?", The Huffington Post, 20 May 2011, at http://www.huffingtonpost.com/jamyang-norbu/who-created-pakistans-nuc b 864124.html.

39 Reed, Thomas C. and Stillman, Danny B. (2009): The Nuclear Express: A Political History of the Bomb and its Proliferation, USA, Zenith Press, p.249.

${ }^{40}$ Ibid., p. 252.

${ }^{41}$ Ibid., p. 254.
} 
Gujaral Doctrine, the policy consisted of a set of five main principles: (1) with 'smaller' neighbors like Bangladesh, Bhutan, Maldives, Nepal and Sri Lanka, India would not ask for reciprocity, but give and accommodate what it can in good faith; (2) no South Asian country should allow its territory to be used against the interest of another country of the region; (3) no country should interfere in the internal affairs of another; (4) all South Asian countries must respect each other's territorial integrity and sovereignty; (5) all disputes should be settled through peaceful bilateral negotiations. The 'Gujral Doctrine' was controversial when it was first unveiled but became the basis for neighborhood policies of latter governments, cutting across political divisions. There seems to be a general consensus that New Delhi must act non-reciprocally towards its neighbors and create stakes for its neighbors in the success of India. ${ }^{42}$ Though the Gujral doctrine primarily aimed at improving India's ties with her smaller neighbors and was not Pakistan specific, it did have some impact on improving bilateral ties.

Indo-Pakistani strained relations have also sought to be explained in geo-strategic terms. The pre-occupation with war-making on the part of Pakistan has been argued to be strategically myopic - indeed pathological - on three counts. First, it has not been militarily successful; second, it has failed to achieve Pakistan's political aims; and, third, it has been very costly. ${ }^{43}$ The nuclear tests of 1998 followed by the Lahore declaration of February 1999 were, initially claimed by sections of the strategic community, would prevent further conventional conflicts because of the nuclear deterrence factor. The Kargil conflict in 1999 proved the optimists wrong. The Kargil adventure of 1999 arguably was the result of the Pakistani military establishments' increasing frustration with India's success in containing the militancy in $J \& K$ to within manageable limits and evaporation of all their hopes and desires to bleed India through a strategy of 'a thousand cuts. ${ }^{44}$ Not only Pakistan's military adventure ended in a failure but she also failed to get any international mileage as the US and most countries praised India's show of restraint in not opening a second front against Pakistan thereby leading to escalation of the conflict. Even China did not come out in support of Pakistan. On a back foot, the Pakistani government had no other option but to withdraw the militants and other regular military contingents. Soon after the Kargil conflict, Pakistan would witness yet another military coup when the army Chief Pervez Musharraf would capture power through a coup in October 1999.

\section{Post 9/11 Developments}

In the post Cold War period one major trend has been internationalization of South Asian regional dynamics. While this is not new, the nature and the intensity of such influence has certainly increased to the level of being considered as a major factor. The prime regional organization in South Asia, the SAARC currently has nine external observers: Australia, China, European Union (EU), Iran, Japan, Republic of Korea (South Korea), Mauritius, Myanmar, and the U.S.A. The SAARC, in recent years, has also sought to diversify its operations by establishing linkages (bilateral and multilateral basis) with external countries or organizations particularly located in Southeast Asia and East Asia.

Direct involvement of external agencies at bilateral level has also markedly increased in South Asia. The US and the NATO's involvement in Afghanistan along with other external

\footnotetext{
${ }^{42}$ Raja Mohan, C.: "The Making of Indian Foreign Policy: The Role of Scholarship and Public Opinion", ISAS Working Paper No.73 (13 July 2009), Singapore, Institute of South Asian Studies, University of Singapore, p.12.

${ }^{43}$ Faruqui, Ahmad: "Pakistan's strategic myopia", The RUSI Journal, vol. 145, no.2 (2000), p.50.

${ }^{44}$ Kanwal, Gurmeet: "Pakistan's strategic blunder in Kargil”, Strategic Analysis, vol. 23, no.5 (1999), p.837.
} 
players have made the Afghan theatre truly global since 2001. Amidst all talks within policy making circles about an imminent US withdrawal from the country, the US Vice President Joe Biden, while on a visit in Afghanistan in January 2011 commented, "If the Afghan people want it, we (United States) won't leave in 2014." ${ }^{45}$ The Taliban government had served a number of Pakistan's interests, from securing its long porous western border to providing the controversial 'strategic depth' and safe corridor for future energy transportation from Central Asia. Pakistan was therefore faced with a dilemma when it was asked to join the US in its war on terror. ${ }^{46}$ Under US pressure it however, decided to join but tried to maintain certain links with sections of the Al Qaeda and the Taliban who could be used for strategic bargaining when time comes.

\subsection{The Afghan Imbroglio}

The country's vital importance lies in its strategic location connecting South Asia and Central Asia. At issue is a vast inter-regional landscape connecting Cetral Asia and West Asia to the Indian subcontinent, with shared roots and whose parts, to a large extent intersect in Afghanistan. ${ }^{47}$ Following the Soviet invasion of 1979 , New Delhi managed to develop cordial relations with the Soviet backed regimes till the Soviet withdrawal and the Taliban take over. During the Afghan civil war, India supported the Northern Alliance and even established and manned a 25-bed hospital at Farkhor (Ayni), Tajikistan for more than a year that aided the Northern Alliance (NA). In fact, when the NA leader Masood was attacked by Al Qaeda suicide bombers on September 10, 2001, he was rushed to this hospital by helicopter where he succumbed to his massive injuries. Based from Tajikistan, India also supplied the NA with high-altitude warfare equipment (worth nearly $\$ 8$ million), and also dispatched several "defense advisers," including an army officer of brigadier rank to provide operational guidance. ${ }^{48}$ Since the fall of the Taliban, New Delhi has been trying hard to emerge as a major strategic partner of Afghanistan. India, for instance, has been playing an activist role in the development of the land locked country. As the sixth largest donor, India has pledged $\$ 1.3$ billion to the Hamid Karzai government in Afghanistan. All its projects are undertaken in partnership with the Afghan government to achieve the goals identified under the Afghan National Development strategy. India's programmes cover four broad areas - infrastructure projects; humanitarian assistance; small and community based development projects; and, education and capacity development.

Pakistan's importance as an ally once again soared as the US and the NATO forces launched its offensive against the Taliban and the Al Qaeda in Afghanistan. In 2004, Pakistan was officially designated as 'a major non-NATO ally' of the United States. Afghanistan provides the easiest access to Central Asia. The western route via Iran is considered to be too long and the eastern route via China is mountainous. ${ }^{49}$ Pakistan also looks upon a friendly Afghan regime as essential for her own strategic depth. The use and dependence upon radical

\footnotetext{
${ }^{45}$ Partlow, Joshua: "Biden: U.S. would support Afghans beyond 2014 target", The Washington Post, 11 January 2011, at http://www.washingtonpost.com/wp-dyn/content/article/2011/01/10/AR2011011002389.html.

${ }^{46}$ Khaliq, Shoaib: "Pakistan's Kashmir Policy in new Strategic Environment”, IPRI Journal, vol. 12, no.1 (Winter 2012), p.47.

47 Roy, Arpita Basu (2008): "The New Regional Approach towards South and Central Asia: An Assessment", in Sengupta, Anita; Vasudevan, H.S.(eds.): Asian Annual 2007: Envisaging Regions, New Delhi, MAKAIAS \& Manohar, p.99.

48 Fair, C. Christine: “Under the Shrinking U.S. Security Umbrella: India's End Game in Afghanistan?”, The Washington Quarterly, vo.34, no.2 (Spring 2011), p. 182.

${ }^{49}$ Memon, Marvi: "Reorientation of Pakistan's Foreign Policy after the Cold War", in Ali, Mehrunnisa (ed.) (2001): Readings in Pakistan's Foreign Policy 1971-1998, Karachi, Oxford University Press \& The Pakistan Institute of International Affairs, p.411.
} 
extremist elements in the process, since the 1980s, however, has tended to convert nationalist or tribal aspirations into ethno-religious in character. One analyst has remarked that during one her talks with a scholar in Pakistan, he commented that what General Zia ul Haq and the Central Intelligence Agency (CIA) and the Inter- Services Intelligence (ISI) managed to do was to turn the essential Afghan nationalist struggle into a holy war. ${ }^{50}$

The US engagement with Pakistan has also continued in spite of it generating significant backlash in the country. According to the results of an opinion poll conducted by the Pew Global Initiative, just $12 \%$ express a positive view of the U.S with most Pakistanis viewing the U.S. as an enemy, considering it a potential military threat, and oppose American-led anti-terrorism efforts. ${ }^{51}$

As one analyst argues:

The generals also think time is on their side - that NATO is doomed to give up in Afghanistan, leaving them free to act as they wish there. So they have concluded that the sooner America leaves, the better it will be for Pakistan. They want Americans and Europeans to believe the war is hopeless, so they encourage the Taliban and other militant groups to speed the withdrawal with spectacular attacks. ${ }^{52}$

Relations between the US and Pakistan has been far from cordial as the US suspects sections of the Pakistani government and the army of still colluding with various factions of the Taliban and the Al Qaeda and not acting firmly enough against the militant groups. Mutual trust deficit has increased since the operation of the US special forces on a closely guarded compound in Abbottabad, 30 miles north-east of Islamabad killing the Al Qaeda chief Osama bin Laden in May 2011. Following the attacks on a NATO outpost south of Kabul and on the US embassy by insurgent groups in September 2011, Admiral. Mike Mullen, the chairman of the Joint Chiefs of Staff, commented that Pakistan's spy agency played a direct role in supporting the insurgents who carried out the deadly attack on the American Embassy in Kabul. ${ }^{53}$ During a visit to Afghanistan and Pakistan in October 2011, the US Secretary of State Hillary Clinton also issued a warning message to the Pakistani establishment by commenting that, "No one should be in any way mistaken about allowing this to continue without paying a very big price." 54

One US Congressman Dana Rohrabacher has recently introduced a resolution in the US House of Representatives calling upon Pakistan to recognize the Baloch right to self determination. The non-binding resolution stated that the people of Balochistan, a sprawling western province racked by a seven-year-old separatist insurgency, should "have the right to

\footnotetext{
${ }^{50}$ Weaver, Mary Anne (2002): Pakistan: In the Shadow of Jihad and Afghanistan, New Delhi, Viking Press, p. 251 .

${ }^{51}$ Pew Global Attitudes Project, , "U.S. Image in Pakistan Falls No Further Following bin Laden Killing", Pew Research Center, 21 June 2011, at http://www.pewglobal.org/2011/06/21/u-s-image-in-pakistan-falls-no-furtherfollowing-bin-laden-killing/.

52 Riedel, Bruce. D: “A New Pakistan Policy: Containment", The New York Times, 14 October 2011, at http://www.nytimes.com/2011/10/15/opinion/a-new-pakistan-policy-containment.html.

${ }^{53}$ Bumiller, Elisabeth and Perlez, Jane: "Pakistan's Spy Agency Is Tied to Attack on U.S. Embassy", The New York Times, 22 September 2011, at http://www.nytimes.com/2011/09/23/world/asia/mullen-asserts-pakistanirole-in-attack-on-us-embassy.html? r=1\&pagewanted=all.

${ }^{54}$ Myers, Steven Lee: "U.S. Officials Deliver Warning in Pakistan Over Extremists", The New York Times, 20 October, 2001, at

http://www.nytimes.com/2011/10/21/world/asia/clinton-issues-blunt-warning-to-pakistan.html?pagewanted=all.
} 
self-determination and to their own sovereign country." 55 This led to a statement being issued by the Pakistani embassy in Washington DC criticizing the resolution and mentioning that, "Balochistan's affairs and issues are an internal matter of Pakistan, and it is for the people of Pakistan and our democratic institutions to address these [issues]."

Separately, a bipartisan group of powerful US lawmakers has asked secretary of state Hillary Clinton to "immediately designate" the Pakistan-based dreaded Haqqani network as a foreign terrorist organization. The letter said it was clear that the Haqqani network continues to launch sensational and indiscriminate attacks against US interests in Afghanistan, and poses a continuing threat "to innocent men, women, and children in the region." ${ }^{, 27}$ In another move, a bill on 'Pakistan Terrorism Accountability Act of 2012' has been introduced in the US Congress that would require the Department of Defense to list all Americans killed by terrorist groups operating with impunity inside Pakistan and Afghanistan and supported by elements of Pakistani government, deducting US \$50 million from the aid to Pakistan for every American citizen killed by such terrorist groups. Dana Rohrabacher, Chairman of the House Foreign Affairs Oversight and Investigations Subcommittee, and the prime mover behind this bill commented, "For too long America has funded the Pakistani government, giving it free money, while elements of the ISI and Pakistan's military operate radical Islamic groups that are actively murdering Americans. Americans will not accept this." ${ }^{58}$

The problem with USA's Af-Pak policy is that it is almost completely ahistorical because it ignores Pakistan's longstanding national security concerns about the disputed Pakistan-Afghanistan border and irredentist Afghan claims on a large swathe of Pakistani territory. These concerns are further compounded by the current Indian involvement in Afghanistan and India's seemingly permanent policy of supporting all anti-Pakistani Afghan governments. ${ }^{59}$ As one analyst points out, “...the fact remains that geography dictates that Pakistan will always play a major role in ensuring the stability of Afghanistan. Arguably, India can be kept out of conflict resolution in Afghanistan, but Pakistan cannot be."60

The US, in fact, in spite of ongoing political rhetoric for public consumption, has been forced to begin negotiations with Pakistan over better border coordination in AfghanistanPakistan border and reopening of Pakistani border routes for supplies to Afghanistan which have been blocked since the US drone attack accidentally killed 24 Pakistani soldiers at a Pakistani army base at Salala checkpoint on the Afghanistan-Pakistan border in November 2011. There is incentive on both sides to resolve the impasse over the NATO supply route. The U.S. has had to spend considerably more money over the past few months shipping supplies to Afghanistan through the more expensive northern route that runs through Central Asia. The route through Pakistan will become even more important as the U.S. begins to pull

\footnotetext{
${ }^{55}$ Walsh, Declan: "Fury in Pakistan after U.S. Congressman Suggests That a Province Leave", The New York Times, 21 February, 2012, at http://www.nytimes.com/2012/02/22/world/asia/fury-in-pakistan-after-us-congressman-suggests-that-aprovince-leave.html? r=1\&pagewanted=all.

${ }^{56}$ The Express Tribune (18 February, 2012), at http://tribune.com.pk/story/338279/us-congressmans-balochistan-resolution-ill-informed-unacceptable/.

${ }^{57}$ The Statesman, 12 May 2012, at http:/ / thestatesman. net/ index. php? option= com content\&view=article\&id=409703\&catid=35.

58 "Pak 'terrorism accountability' bill introduced in US Congress", The Tribune, 12 May 2012, at http://www.tribuneindia.com/2012/20120513/world.htm\#1.

${ }^{59}$ Khan, Feisal: "Why Borrow Trouble for Yourself and Lend It to Neighbors? Understanding the Historical Roots of Pakistan's Afghan Policy", Asian Affairs: An American Review, vol. 37, no.4 (2010), pp.172-173.

${ }^{60}$ Bhadrakumar, M.K.: "NATO Weaves South Asian Web", Asia Times Online, $23^{\text {rd }}$ December 2010, at http://www.atimes.com/atimes/South_Asia/LL23Df06.html.
} 
out equipment as it withdraws most of its combat troops from Afghanistan by the end of 2014. On the other hand, Islamabad is eager to free up more than a billion dollars in U.S. military aid that has been frozen for the past year and would likely only be released once the supply route is reopened. ${ }^{61}$

If Pakistan successfully eliminated the threat of Islamists, its utility to Washington and the fear of the alternative would disappear and the flow of US money would stop. If it failed to show any tangible progress, it would be have been toppled. So it plays both ends against the middle brilliantly. ${ }^{62}$ But the strategy is leading to immense collateral damage inside the country. One analyst in fact had predicted in 2009:

The religious militants Islamabad is empowering today to create problems for the democratically elected government in Kabul could well turn their sights on their benefactors in Islamabad at some future point, just like the Pashtun nationalists might. Should the jihadis do this, it would not be the first time the religious militants turned on their patron. This is what happened with the mujahideen the Americans and the Saudis empowered to defeat the Soviets, after all. Out of these armies emerged al-Qaeda. ${ }^{63}$

During 2005-2006, Musharraf forged a deal with the tribal leaders of in South and North Waziristan which stopped army raids in the tribal strongholds in return for a pleadge that the tribal leaders would not let the Taliban or the Al Qaeda forces to cross over into Afghanistan attacking the NATO forces. This has not prevented further radicalisation in Pakistani society. Islamist groups are more vociferous against perceived western hegemony defining it in cultural as well as economic and political terms finding sympathy and support within a broad spectrum of Pakistan's populace, increasingly disillusioned by the country's elite dominated authoritarian and semi-feudal socio-economic and political structure. ${ }^{64}$

\subsection{The China Factor}

It has been argued that overall, the Pakistan factor has played a minimal role in interfering with the development of Sino-Indian relations since Pokhran II,. and Sino-Indian relations have improved considerably in the context of increasing bilateral trade and thus, "Pakistan will likely shift to more and more of a bilateral issue between China and India rather than a triangular one as during the Cold War." 65

It has also been argued that China is becoming more wary of the deteriorating internal situation in Pakistan and hence giving indications that it is no longer going to commit herself without carefully analyzing the pros and cons. As one author writes:

\footnotetext{
${ }^{61}$ Bangash, B.K.: "US commander holds talks with Pakistan army chief on coordination along Afghan border", The Washington Post, 12 may 2012, at http://www.washingtonpost.com/world/asia_pacific/pakistan-bombtargeting-police-kills-1-officer-wounds-17-people-in-northwest/2012/05/12/gIQAXrmaJU_story.html.

62 Thakur, Ramesh: "Delinking Destiny from Geography: The Changing Balance of India-Pakistan Relations", India Quarterly: A Journal of International Affairs, vol.67, no.3 (September 2011), p.203.

${ }^{63}$ Rahmani, Waliullah (2009): "The new Great Game: The Contest for Afghanistan”, in Behuria, Ashok K. (ed.): South Asia: The Quest for Regional Cooperation, New Delhi, Institute for Defence Studies and Analyses (IDSA), p.130.

${ }^{64}$ Rais, Rasul Baksh: “Assessing the threat of Islamic Revivalism in Pakistan”, in Jetly, Nancy (ed.) (1999): Regional Security in South Asia: the Ethno-Sectarian Dimensions, New Delhi, Lancer's Books, pp.294-295.

${ }^{65}$ Atwal, Amardeep (2008): China-India Relations: Contemporary Dynamics, UK, Routledge, p.120.
} 


\begin{abstract}
China's calculus in Pakistan is becoming more diverse. The central question will be the extent to which political, and especially investment, risks begin to complicate the straightforward geopolitical calculus that has long yielded a remarkable intimacy between Beijing and Islamabad. To be sure, Beijing is too strategically tied to Pakistan -- and too timid in its diplomacy, in any case -- to off-load an erstwhile ally. But China is unlikely to be such an accommodating patron, either. ${ }^{66}$
\end{abstract}

There are several indications of the Chinese becoming more wary about getting involved in Pakistan. The Gwadar port in Baluchistan, coast for instance, was built under Chinese help and supervision was completed in 2005. Local land deals have, however, alienated the Balochis and seemed to have favored the ruling Punjabi elite groups. ${ }^{67}$ Balochistan has seen repeated attacks on Chinese nationals, including a 2004 bombing that killed three engineers working at the Gwadar port and a 2006 attack on a bus near Hub. In response to one kidnapping case, conducted by elements associated with the Lal Masjid in Islamabad, Beijing put tremendous pressure on the Pakistan army to intervene. In September 2011, Kingho, a large private Chinese miner, is reported to have abandoned a proposed $\$ 19$ billion investment to build a coal mine and power and chemical plants in Pakistan's Sindh province after reassessing investment and security risks. ${ }^{68}$

This, however, does not mean bilateral engagement has completely stopped. China's recent decision to sell two civilian reactors to Pakistan has caused some controversy because the exact nature of the nuclear agreement is not known. Beijing has sought to convey that all Chinese sales to Pakistan are ipso facto exempted from its obligation to uphold the NSG's requirement of full-scope safeguards because China joined the Nuclear Suppliers Group (NSG) only in 2004, well after the latest "understanding" reached with Pakistan. ${ }^{69}$

\title{
6: Current Trends in Indo-Pak Bilateral Relations
}

\subsection{Overview}

Following Pakistan's decision to cooperate with the US and the NATO led operations in Afghanistan, there were hopes generated that the incidence of Islamic terror would recede in the subcontinent. Such hopes have, however, been belied. While Pakistan itself faces the wrath of terror groups it had nurtured so far, bases from that country and support from sections of the army and ISI network have helped some of these terror networks in launching a series of daring attacks on India during this period. Following the Agra Summit of May 2001 between the Indian Prime Minister Vajpayee and Pakistan's President General Musharraf, terror groups carried out an attack on the Jammu and Kashmir state legislative assembly complex exploding a car bomb and suicide bombers. Soon in a more daring attack, the Indian parliament building was targeted on 13 December, 2001 leading to a crisis like

\footnotetext{
${ }^{66}$ Feigenbaum, Evan A.: "China's Pakistan Conundrum: The End of the All Weather Friendship", Foreign Affairs, 04 December 2011, at http://www.foreignaffairs.com/articles/136718/evan-a-feigenbaum/chinaspakistan-conundrum?page $=2$.

${ }^{67}$ Ray, op. cit., p.196.

${ }^{68}$ Feigenbaum, op.cit.

69 Tellis, Ashley J.: "The China-Pakistan Nuclear "Deal”: Separating Fact From Fiction”, Carnegie Policy Outlook (16 July 2010), p.4, at

http://www.carnegieendowment.org/files/china_pak_nuke1.pdf.
} 
situation. Following India's accusation, the US government put two Pakistani based jihadi groups, Lashkar-e-Taiba (LeT) and Jaish-e-Muhammad (JeM), in its designated terrorist list. The Indian High Commissioner was recalled from Islamabad and Indian troops were deployed along the Indo-Pak border. The Delhi-Lahore bus service, formally inaugurated during Prime Minister Vajpayee's Lahore diplomacy in 1999, was temporarily suspended in 2001. Though there was a perceptible thaw in relations again from 2004, terror incidents have been frequent. The Mumbai suburban train bombings of 2006, for instance, leading to over 200 deaths and 700 hundred injured was blamed to have been the handiwork of Pakistan based terrorists. The 2007 Samjhauta Express train bombing again claimed lives of 68 people, an incident which was condemned by both the governments. This was followed by another series of attacks launched by terrorist gunmen attacking and indiscriminately killing people at various locations in Mumbai including the famous Taj hotel in 2008.

In spite of bilateral tension, efforts to restrain and minimize conflict situation through various Confidence building Measures (CBMs) have been attempted. CBMs, it has been argued, is not a new phenomenon between Pakistan and India. They have existed and been built upon as early as 1949 with the Karachi Agreement on CFL in Kashmir and over the years there have also been communication measures, notification measures, transparency measures consultation measures, declaratory measures, and so on. ${ }^{70}$ Steps have been taken to increase the level of road and railway connectivity between the two countries apart from the existing air connectivity in order to help common people on both sides by offering them more affordable choices. Apart from the old Samjhauta Express connecting the Pakistani city of Lahore with the Indian town of Attari(New Delhi serves as end terminus), operating since 1970s, The Thar Express is the other passenger railway link between the two countries, running from Karachi(Pakistan) to Jodhpur(India) which began to operate since 2006.

The Delhi-Lahore bus service has also been resumed since 2003. A MuzaffarabadSrinagar bus service linking Indian controlled Kashmir and the POK was launched in 2005 and both countries agreed to open trade across LOC. A bus service connecting Poonch (India) with Rawalkote (Pakistan) over $55 \mathrm{~km}$ was also launched in 2006 along with another bus service from Amritsar (Indian Punjab) to Lahore(Pakistan) and between Amritsar and Nankana Sahib(Pakistan) in the same year. In 2007, India also allowed the APHC(All Party Hurriyat Conference) leadership to visit Pakistan and also agreed to open the Line of Control (LOC) at a few places to allow people to people contact between Kashmiris residing on both sides of the LOC. The Indian government has also appointed a three member team of interlocutors who would present their own report and recommendations to the government.

From the Pakistani side, General Musharraf suggested a seven region formula in 2004. While not entirely new, Musharraf's proposal is to divide Jammu and Kashmir into seven regions, two of which would be in Pakistan and five in India. The regions are: the plains including Jammu, Pir Panjal, the valley, the Great Himalayan zone, the Northern Areas, upper Indus valley and the parts that are with China. The proposal spoke of identification of the regions, then introduce gradual demilitarization in the identified regions, and finally after the first two steps were completed, a change in the status of the regions was sought. Musharraf elaborated on his proposal by suggesting that the identification of the regions could be carried out keeping either of the following factors in mind: ethnicity, religion or geographic

\footnotetext{
70 Mazari, Shireen M.: "Confidence-Building Measures in Kashmir: A Pakistani Perspective”, Economic and Political Weekly, vol. 40, no. 28 (Jul. 9-15, 2005), pp. 2998-2999.
} 
proximity. ${ }^{71}$ No concrete steps have been taken by the countries to consider these proposals so far. There have also been recent proposals to demilitarize the Siachen glacier. Both President Zardari and the Pakistan Army chief General Kayani have made such proposals after the massive avalanche at Gayari struck the 6th Northern Light Infantry (NLI) battalion headquarters and caused the death of about 140 Pakistani soldiers. Thus, both sides seem to show signs and willingness to at least talk to each other on issues which were considered to be non-negotiable in the recent past.

\subsection{Water Woes}

The Indus river which rises in Tibet and flows some 2,800 km through India and Pakistan to its mouth in the Arabian Sea, has been the subject of controversy since the Partition of British India into dominions of India and Pakistan as the partition cut the Indus basin into two. ${ }^{72}$ Differences over the provisions of the 1960 Indus Water sharing treaty is another problem between India as the upper riparian and Pakistan as the lower riparian state. While the major provisions of the World Bank brokered treaty has been more or less respected, disputes have risen over interpretations of certain clauses. In 1970s, for instance construction of the Salal hydroelectric project in Jammu and Kashmir generated dispute. At present there is an unresolved dispute regarding what is known as the Tulbul Navigation project (known as the Wular barrage project in Pakistan) involving building of a barrage on the River Jhelum, at the mouth of Wullar Lake, India's largest fresh water lake, near Sopore town in Kashmir Valley. Pakistan took the case to Indus Waters Commission in 1986 which admitted its failure to resolve the issue. Before Pakistan moved International Arbitral Court, India stopped construction. ${ }^{73}$ Several rounds of bilateral talks have failed to produce any agreement so far. In a recent round of Waters resources Secretary level talks India is learnt to have told Pakistani delegates that it would prefer the option of seeking international arbitration to resolve the over two-decade old dispute. ${ }^{74}$ One Pakistani scholar, for instance has argued that India's holding back the waters of rivers flowing from Kashmir as a clear violation of the Indus Water Treaty(1960) along with plan to build 12 hydropower projects on the Kabul River in Afghanistan intensify the water war against Pakistan. ${ }^{75}$ Disputes have also arisen over the construction of the Baglihar dam on the Chenab river in the southern Doda district, on the Indian side of Jammu and Kashmir, and the Kishenganga project. Though construction of this dam was started in the 1990s, Pakistan Government objected to stall the construction of Baglihar Dam by invoking the Article 9A of the Indus Water Treaty. When bilateral negotiations failed, Pakistan referred the Baglihar case to the World Bank, and the Kishenganga project to the International Court of Arbitration for adjudication. The expert appointed by the World Bank gave his report in 2007. Further works currently remain stalled on both the projects. This led the Jammu and Kashmir state legislature to pass a resolution in 2002 calling for a review and annulment of the Indus treaty. It has been argued by analysts that the Indus Treaty of 1960 is overwhelmingly generous to Pakistan. According to Brahma Chellaney, for instance:

\footnotetext{
71 Khaliq, Shoaib: “Pakistan's Kashmir Policy in new Strategic Environment”, IPRI Journal, vol. 12, no.1 (Winter 2012), p.55.

${ }^{72}$ Mohanty, Tapan R. and Khan, Adil Hasan: "Dam of Division: Understanding the Baglihar Dispute", Economic and Political Weekly, vol. 40, no. 29 (Jul. 16-22, 2005), p.3155.

73 "Wullar Barrage/Tulbul Navigation Project", Times of India, 29 July 2004, at http://timesofindia.indiatimes.com/world/Wullar-Barrage/Tulbul-Navigation-Project/articleshow/794689.cms.

74 "Tulbul dispute: India seeks international arbitration", The Economic Times, 28 March 2012, at http://articles.economictimes.indiatimes.com/2012-03-28/news/31249708_1_kishenganga-project-tulbul-induswater-treaty.

75 Chandio, Khalid: "Water Security: Pakistan and Regional Perspective", IPRI Journal vol, 12, no. 1 (Winter 2012), p.136.
} 
India signed an extraordinary treaty indefinitely setting aside $80.52 \%$ of the Indus-system waters for Pakistan - the most generous water-sharing pact thus far in modern world history...In fact, the volume of waters earmarked for Pakistan from India under the Indus treaty is more than 90 times greater than what the US is required to release for Mexico under the 1944 USMexico Water Treaty. ${ }^{76}$

Pakistan, on the other hand, whose agriculture dominated economy is heavily reliant on the Indus and its tributaries, accuses India of denying its legitimate share of water. According to a Times Report much of this water scarcity has been a result of haphazard water management policies, unproductive agricultural practices, dilapidated infrastructure and grossly inadequate water storage facilities along with climate change which could reduce the flows of the Indus by 8 percent in $2050 .^{77}$ What is a matter of concern is recent attempts of Pakistan based militant groups to use water scarcity to whip up anti-India sentiments. In 2010, for instance, a protest meeting was organized by some extremist organizations involving thousands of farmers driving tractors and carrying signs warning: "Water Flows or Blood" accusing India of 'water terrorism. ${ }^{78}$

\subsection{The 'Guns or Butter' Choice}

Given continuance of bilateral tension, South Asia has become one of biggest arms importing region in the world. While both the countries became overt nuclear weapons states in 2008, conventional arms import has also increased (see table 1 below). Both countries invest heavily in boosting up their defense potential and enhancing the conventional capability of their armed forces and also upgrading of the respective missile programmes.

\footnotetext{
${ }^{76}$ Chellaney, Brahma: "Water treaties \& diplomacy: India faces difficult choices on water", The Economic Times, 10 May 2012, at http://economictimes.indiatimes.com/opinion/guest-writer/water-treaties-diplomacy-india-faces-difficultchoices-on-water/articleshow/13073011.cms?curpg=1.

${ }_{77}$ Mandhana, Niharika: "Water Wars: Why India and Pakistan Are Squaring off over Their Rivers", Time, 16 April 2012, at http://www.time.com/time/world/article/0,8599,2111601,00.html.

${ }_{78}$ Brulliard, Karin: "Rhetoric grows heated in water dispute between India, Pakistan", The Washington Post, 28 May 2010, at http://www.washingtonpost.com/wp-dyn/content/article/2010/05/27/AR2010052705393.html.
} 
Table 1. INDIA PAKISTAN DEFENCE EXPENDITURE (US \$ bn) ${ }^{79}$

\begin{tabular}{|l|l|l|l|l|l|}
\hline & 2010 & $\begin{array}{l}\text { \% of } \\
\text { Regional } \\
\text { Total }\end{array}$ & 2011 & $\begin{array}{l}\text { \% of } \\
\text { Regional } \\
\text { Total }\end{array}$ & $\begin{array}{l}\text { Real \% } \\
\text { Change }\end{array}$ \\
\hline INDIA & 29.66 & $11.44 \%$ & 31.88 & $10.85 \%$ & $-2.2 \%$ \\
\hline PAKISTAN & 4.47 & $1.73 \%$ & 5.16 & $1.76 \%$ & $2.2 \%$ \\
\hline SOUTH ASIA & 35.95 & $13.88 \%$ & 39.19 & $13.33 \%$ & $-1.12 \%$ \\
\hline
\end{tabular}

Huge expenditure on defense, however, restricts the available allocation for development purposes. This is particularly alarming as chronic poverty and underdevelopment continues to be the most pernicious threat to human security in the region. With 20 per cent of the world population and constituting only about 5 per cent of the world area and that too with high rate of density, teeming millions in the region continue to wallow in poverty and destitution, which in turn gives rise to numerous socio-political ills. The need for enhancement of regional human security is particularly being felt in the context of the region recently experiencing the process of globalization. The process of globalization has resulted in greater unevenness mainly benefiting the developed world, while in the developing world; the benefits have accrued only to a few developing countries. Even in the developing countries enjoying the benefits of globalization such impact have not necessarily been felt across the spectrum. The process of undertaking globalization has involved a combination of structural changes and shifting emphasis from the state to the market with the objective of closer interaction and interconnection between the domestic and the global economy. This, however, has also not been a case of unmixed blessing. Moreover, large sections of the already impoverished population have found themselves, most often, at the receiving end of such policies. Thus, in spite of experiencing economic growth, South Asia, continues to be one of world's most underdeveloped regions which affects both India and Pakistan. Table 2 below presents some basic human development indicators for both the countries

\footnotetext{
${ }^{79}$ Chapter Six: “Asia, The Military Balance”, Table 18 in The Military Balance 2012, vol. 112, no. 1 (2012), London, IISS, p. 209.
} 
Table 2. INDIA \& PAKISTAN HUMAN DEVELOPMENT INDICATORS ${ }^{80}$

\begin{tabular}{|c|c|c|c|c|c|c|c|c|}
\hline$\underline{\text { Country }}$ & HDI Rank & $\begin{array}{l}\frac{\text { Human }}{\text { Develo }} \\
\text { pment } \\
\underline{\text { Index }(} \\
\underline{\text { HDI })} \\
\underline{\text { Value }}\end{array}$ & $\begin{array}{l}\frac{\text { Life }}{\text { expectancy }} \\
\underline{\text { at birth }} \\
\underline{\text { (years) }}\end{array}$ & $\begin{array}{l}\frac{\text { Mean }}{\text { years }} \\
\text { of } \\
\underline{\text { schooling }} \\
\underline{\text { (years) }}\end{array}$ & $\begin{array}{l}\text { Expected } \\
\text { years of } \\
\text { schooling } \\
\underline{\text { (years) }}\end{array}$ & $\begin{array}{l}\frac{\text { Gross }}{\text { national }} \\
\underline{\text { Income }(\text { GNI) }} \\
\text { per capita } \\
\underline{\text { (constant }} \\
\underline{\text { Po05 }} \\
\underline{\text { Ppp \$) }}\end{array}$ & $\begin{array}{l}\frac{\text { GNI }}{\text { per }} \\
\underline{\text { capita }} \\
\underline{\text { rank }} \\
\underline{\text { minus }} \\
\underline{\text { HDI }} \\
\underline{\text { rank }}\end{array}$ & $\begin{array}{l}\text { Non income HDI } \\
\text { value }\end{array}$ \\
\hline INDIA & 134 & 0.547 & 65.4 & 4.4 & 10.3 & 3,468 & -10 & 0.568 \\
\hline PAKISTAN & 145 & 0.504 & 65.4 & 4.9 & 6.9 & 2,550 & -7 & 0.526 \\
\hline
\end{tabular}

Improving economic relations could go a long way in improving bilateral ties. The prime regional organization, the SAARC, however, is yet to make any substantial impact even after 27 years since its creation in 1985. In spite of the introduction of trade liberalisation schemes like the SAPTA (SAARC Preferential Trading Arrangement)(1995) and SAFTA (South Asia Free Trade Area)(2004), the level of intra-regional trade continues to remain low, hovering between 4 and 6 percent only. India-Pakistan official trade (as a proportion of Pakistan's total international trade) steadily declined from nearly $20 \%$ in the early 1950 s, plummeting to almost zero after their war in 1965, and has shown some signs of recovery in the 1990s. But it is still below the levels of the 1950s, which was shortly after the two nations were separated politically. ${ }^{81}$ According to current estimate, India's export to Pakistan in 2010-2011 was US \$ 2,333.62 million which was 0.92 percent of India's total export and her import from Pakistan (2010-2011) was US \$ 332.51 million amounting to 0.08 percent of India's total import for the same period. ${ }^{82}$ Trade integration between the two countries continues to be affected by

\footnotetext{
${ }^{80}$ Human Development Report 2011, UNDP, p.129, at http://hdr.undp.org/en/media/HDR_2011_EN_Table1.pdf.

${ }^{81}$ Murshed, Syed Mansoob and Mamoon, Dawood: "Not loving thy neighbour as thyself: Trade, democracy and military expenditure explanations underlying India --Pakistan rivalry", Journal of Peace Research, vol. 47 , no.4 (July 2010), p.464.

${ }^{82}$ Export Import Data Bank, Ministry of Commerce, Government of India, at http://commerce.nic.in/eidb/ecntq.asp.
} 
political antagonism which is reflected in high tariff and non-tariff barriers raised by both countries. $^{83}$

A recent study estimates that potential two- way trade between India and Pakistan can be about 10 times than its rather unsatisfactory current level and identifies major sectors for trade (export and import) possibilities between the two countries which are: textiles, agriculture, engineering, chemicals, electronics and metals and minerals. In addition, there is a large scope in trade in several service sectors such as health, entertainment services, information technology, energy and tourism. ${ }^{84}$ In this connection the announcement of the present government in Pakistan to grant MFN status to India is a step in the right direction. While defending the government's decision in the Senate, Pakistan's Commerce Minister Makhdoom Amin Fahim argued that the purchasing power of Pakistani consumers will increase with the grant of MFN status to India because they will have access to goods at competitive rates and the local industry would gain access to the large Indian market with a customer base estimated between 300 and 500 million consumers. ${ }^{85}$

There is also huge prospect in engaging both the countries in regional energy trade network. As early as 1999 a plan was mooted to supply oil and natural gas from Iran to India through an overland pipeline through Pakistan. Stretched over 2775 kilometers, the pipeline could carry natural gas from South Pars gasfield(Iran) to India through Baluchistan and Sindh in Pakistan. This proposal, however, became stalled due to differences over operational costs and intense US pressure on both India and Pakistan to minimize their economic interactions with Iran as a part of their overall strategy to economically starve Iran. Another important regional project is the TAPI (Turkmenistan-Afghanistan-Pakistan-India) gas pipeline project the transit fee mechanism of which has been finalized recently. India and Pakistan are also involved in negotiations in beginning a project involving joint development of a gas field in Turkmenistan. Recently, India has also offered to export gasoline, diesel, jet fuel and fuel oil besides sulfur, polyethylene and polypropylene to Pakistan. Importing these petroleum products from India would help cash starved Pakistan by saving freight costs as several Indian refineries are located close to the border between the countries. ${ }^{86}$

Environmental/ecological security issues, particularly associated with the lopsided development projects, have become another major paradigm within the field of Nontraditional Security in recent years. In the case of South Asia, for instance, it has been argued:

Environmental-induced conflicts are not independent and isolated
occurrences but instead are part of broader regional conflicts based on
territorial dispute, cross-border migration, differing security perception and
ethnic and religious animosity in which environmental issues can become
additional sources of sub-national or inter-state conflict.

Recent estimates indicate that in South Asia, 42 per cent of the land is affected by one or other factors that cause land degradation. Half of the region's dry lands face the threat of

\footnotetext{
83 “The Case for Trade within South Asia”, Policy Brief, no.4 (June 2010), Islamabad Mahbub ul Haq Human Development Centre.

${ }^{84}$ Taneja, Nisha: “India-Pakistan Trade”, Working Paper, no. 182 (June 2006), New Delhi, ICRIER, p.39.

85 "Granting MFN status to India will benefit Pakistan: Fahim”, The Dawn, 18 January 2012.

${ }^{86}$ Sharma, Rakesh and Choudhury, Shantanu: "India, Pakistan Announce Joint Energy Initiatives", The Wall Street Journal, 25 January 2012, at http://online.wsj.com/article/SB10001424052970203806504577182301242396574.html.

87 Sinha, Uttam Kumar: "Environmental Stresses and their Security Implications for South Asia", Strategic Analysis, vol.30, no.3 (July-September 2006), p.613.
} 
desertification, with as much as 63 million hectares of rain fed cropland and 16 million hectares of irrigated land having been lost due to it, especially in India and Pakistan. Onefourth of Pakistan's total land area is facing serious threats of water and wind erosion. Joint planning over judicious use of fund resources is necessary to tackle some of these issues on an urgent basis.

\section{Track II Approach: Pros and Cons}

While not altogether absent before, non-official approaches involving multi-track level interactions are being increasingly projected in the post Cold War period as important means towards reduction of existing tension and mistrust and in improving relations between hostile entities. The primary objectives of Track II diplomacy are three fold: to make attempts to resolve ongoing disputes; to discourage and prevent the emergence of new disputes; and to make efforts to bring two estranged countries and societies closer by introducing CBMs. ${ }^{88}$ Non-official dialogues in the South Asia region, particularly in the context of Indo-Pakistan interaction, however, continue to face several obstacles. Some of these which have been pointed out are:

The most basic is the prevailing atmosphere of mistrust in the region, especially in the India-Pakistan relationship, not only between governments but also between civil society organizations and government officials. Second is the geopolitical asymmetry of the region. Third, political fragility in much of South Asia makes it difficult for governments to take initiatives on issues which opposition parties can exploit. Fourth, organizing regional dialogues can be enormously difficult at a logistical level due to the difficulty of obtaining visas, the absence of reliable telephone lines, and poor airline connections. Fifth, dialogue organizers often do not conduct sufficient preparatory research and consultation or postdialogue follow-up activities. Rarely have they found ways to communicate their results effectively to a broader public. ${ }^{89}$

In spite of numerous initiatives taken especially since the 1990s some of which have been successful in establishing civil society dialogues and organizational networks and forums taking joint initiatives, the track II process has, however, continued to suffer from an overall elite bias. Proliferation of grassroots level organizations and forums are required on a larger scale which could broad base people to people contact between the two countries. Recent announcements of visa relaxation could also go a long way in helping the process at popular level.

\footnotetext{
${ }^{88}$ Cheema, Pervaiz Iqbal: "The Contribution of Track II towards India-Pakistan Relations", South Asian Survey, vol. 13 , no. 2 (206), p.213.

89 Behera, Navnita Chadha; Evans, Paul M. and Rizvi, Gowher (1997): Beyond Boundaries : A Report on the State of Non-official Dialogues on Peace, Security \& Cooperation in South Asia, Canada, University of TorontoYork University, pp.5-6.
} 


\section{Conclusion}

India-Pakistan relations, thus, continue to evolve through numerous twists and turns. In reality, much of Indo-Pakistan bilateralism continues to get shaped by dominant perceptions of national identity. It has been argued for, instance:

Identity has been particularly central to Pakistan's politics and, more important, Pakistani identity has largely evolved not in terms of any indigenous cultural or civilizational values but in contradistinction to the idea of India.

In India too, identity mattered...However, India does not depend on identity for legitimacy, stability, and survival in the manner that Pakistan does. Moreover, Indian identity is not dependent on Pakistan. Therefore the implications of identity for conflict and peace are somewhat different in the two countries; and identity plays a more central role in Pakistan than it does in India. ${ }^{90}$

This has, however, led to Pakistan facing a series of crisis bring the future of the nation-state to a question. A sense of fatigue and despondency regarding the fate of the country seems to have gripped the nation. Roedad Khan, a retired senior diplomat for instance, wrote back in 1997:

Pakistan today presents an image of a country plagued by political, ethnic, and sectarian divisions. Never before has the public faith in the country's future sunk so low...The country as a whole appears to be adrift, lacking confidence about its future. ${ }^{91}$

This of course, does not mean than an alternative vision is totally absent. One analyst argues that it is seldom mentioned that Pakistan's more than 80 million women are involved in struggle for the repealing of laws that discriminate against women. Numerous nongovernmental organizations (NGOs), human rights organizations, academics, lawyers, street theater groups, peasant organizers, and journalists are also working to expose the repression perpetrated by successive authoritarian regimes. ${ }^{92}$ But such voices often get marginalized by the loud rhetoric of extremist elements in society. But cooperation is a necessity if ameliorating the hardships of the masses in terms of human development is seriously considered by the policymakers in both the countries. As one writer notes:

By history and geography, the fates of India and Pakistan are tied together.

They can work to improve the living standards and quality of life of their

\footnotetext{
${ }^{90}$ Nasr, Vali: "National identities and the India-Pakistan conflict", in Paul, op. cit., p.179.

${ }^{91}$ Khan, Roedad (1997): Pakistan-A Dream gone Sour, Oxford, Oxford University Press, p.201.

${ }_{92}$ Munir, Imran: "From Independence to Fundamentalism: Pakistan's Search for Identity", Critical Asian Studies, vol.39, no.4 (2007), p. 619.
} 
two peoples, and those of others in the region; or they can fight to keep each other at the bottom of the international league. ${ }^{93}$

Any right thinking person and policymaker would agree that the first one is a better option. The problem is 'right thinking' is not always the obvious course of action in international relations. It has also been argued that the IR scholars making 'occidental' attempts to explain conflict between India and Pakistan in terms of westernized models often end in failure as they do not analyze the indigenous issues and concerns in a proper manner. ${ }^{94}$ According to Mattoo, the Indian policymaking community in Pakistan consists of three primary categories: 'Subedars'(army chiefs) in favor of a pro-active hawkish policy; the 'Saudagars'(merchants) who are in favor of bypassing Pakistan in favor of greater global economic engagement; and the 'Sufis'(Minstrel mystics) who want India promoting a policy of peace-even to the extent of making unilateral concessions. ${ }^{95}$ The dominant trend in policymaking continues to be imbued by exuberant nationalism symbolized and displayed in full splendor through the flag lowering ceremony conducted at the Wagah border every evening accompanied by ritualized competitive marching and stomping by uniformed personnel from the Pakistani Rangers and the Indian Border Security Force (BSF). ${ }^{96}$ Another low key symbolic ritual is also practiced by Indian and Pakistani peace activists on $14^{\text {th }}-15^{\text {th }}$ August (celebrated as independence days in Pakistan and India respectively) every year by lighting candles at the Wagah border. It is ultimately up to the two nations to decide which symbolic act captures their imagination.

\footnotetext{
${ }^{93}$ Rehmat, Adnan: "A South Asia that I am not Shameful or Sad about", in Banerjee, Dipankar (ed.) (2002): Shaping the Future: A South Asian Civil Society Dialogue, Colombo, Regional Centre for Strategic Studies (RCSS), p.13.

94 Mattoo, Amitabh: "India-Pakistan relations: Towatds a grand Reconciliation", in Das, Suranjan and Chakrabarti, Shantanu (eds.) (2009): Challenges of Nation-building in Developing Societies: Vignettes from West and South Asia, Kolkata, KP. Bagchi, p. 103

95 Ibid., pp. 103-118.

${ }^{96}$ For details on significance of the border in Indo-Pakistan relations see, Purewal, Navtej: "The Indo-Pak border: displacements, aggressions and transgressions", Contemporary South Asia, vol, 12, no.4 (2003), pp. 539556.
} 